\title{
PENGARUH ROTASI KERJA TERHADAP KEPUASAN KERJA DALAM MEMPENGARUHI KINERJA TENAGA KEPENDIDIKAN
}

\author{
Diah Aryanti Sapto Warsi \\ Fakultas Ekonomi \\ Universitas PGRI Yogyakarta \\ diahsukhemi@yahoo.co.id
}

\begin{abstract}
The most important resources of an organization is human resouces, those giving all energy, Tlent, creativity, and effort. It is difficult for an organization to pursue its aim without having capable human reresources. Job rotation and satisfaction are parts of quality human resources management to enhance staff performance. Rotation can inprove knowledge, capability, and minimize burmout. Job satisfaction can enhance job performance.

The Purpose of this study is to investigate wheter rotation influences job satisfaction and permormance job sastifaction influences performance of 93 staffs using partial least square analysis. This study shows that rotation has asignificanly positive influences performances and rotation. Rotation is an effective way to enhance capability and knowledge, and minimize burnout, but it should consider the competency-based placement.
\end{abstract}

Keyword : job rotation, job satisfaction, staff performance.

\section{PENDAHULUAN}

Ramires, 2007 mengemukakan produk utama dari suatu perguruan tinggi merupakan intangibles asset yang selanjutnya dapat di gunakan oleh dunia usaha dan pemerintah untuk meningkatkan nilai tambah produk, maka perguruan tinggi harus meningkatkan upaya peningkatan daya saing. Tolak ukur pelayanan jasa yang baik bukan tolak ukur yang absolute, melainkan tolak ukur yang relatif, dengan kata lain Perguruan Tinggi harus meningkatkan mutu yang baik sesuai dengan kebutuhan pelanggan yaitu peserta didik dan stakeholder. Ketatnya tingkat persaingan sumberdaya manusia, baik dalam bisnis maupun dalam organisasi mengakibatkan organisasi dihadapkan pada tantangan untuk dapat mempertahankan kelangsungan hidup.

Tenaga kependidikan sebagai salah satu aset sumber daya manusia dalam perguruan tinggi dalam mencapai tujuan organisasi, kualitasnya harus diperhatikan termasuk softkill yang dimiliki. Memper-hatikan hal tersebut salah satu cara yang dapat di lakukan adalah dengan rotasi pekerjaan. Rotasi kerja akan memberikan dampak positif bagi karyawan (tenaga kependidikan), karena perputaran pekerja-an tersebut dapat menghindarkan rasa jenuh atau bosan terhadap pekerjaan yang dilaksanakan. Pelaksanaan rotasi juga harus mempertimbangkan karyawan yang sudah merasa mapan dengan posisi dalam pekerjaannya karena mereka akan protes dengan adanya rotasi pekerjaan tersebut.

Pelaksanaan rotasi pekerjaan harus menggunakan kebijakan berdasarkan pada data dan informasi yang akurat mengenai kinerja individu, pengalaman kerja di unit, keterlibatan pelatihan dan perilaku karyawan (Mangkupawira, 2009). Penilaian tersebut dapat dipakai untuk mengetahui tingkat kemampuan masing-masing karyawan sebagai salah satu pertimbangan melakukan rotasi kerja, hal ini dapat pula diartikan bahwa rotasi kerja dilakukan demi peningkatan kompetensi karyawan, penyegaran dari kejenuhan rutinitas, dan penyegaran wawasan. Rotasi pekerjaan juga mendorong adanya penambahan kemampuan dan perilaku dari karyawan lama serta untuk orientasi dan penempatan karyawan baru, dengan begitu di harapkan rotasi pekerjaan dapat memberi dampak pada kepuasan kerja karyawan. 
Faktor kepuasan kerja karyawan dalam suatu organisasi merupakan hal yang sangat penting. Tenaga kependidikan yang mempunyai tingkat kepuasan kerja yang baik akan bekerja dengan rajin dan penuh inovatif atau berperilaku positif terhadap pekerjaannya, dan sebaliknya apabila tingkat kepuasan rendah, maka prestasi karyawan rendah dan bahkan berperilaku negatif terhadap pekerjaannya sehingga timbul rasa malas, tidak disiplin dalam bekerja dan lain-lain, dimana hal tersebut berpengaruh terhadap kinerja karyawan dalam organisasi. Untuk itu organisasi atau perusahaan perlu memperhatikan masalah kepuasan kerja sehingga kinerja karyawan meningkat dan kelangsungan hidup organisasi dapat dipertahankan.

Studi penelitian ini meneliti "Pengaruh Rotasi Kerja terhadap Kepuasan Kerja dalam Mempengaruhi Kinerja Tenaga Kependidikan". Populasi penelitian ini adalah tenaga kependidikan Universitas Sarjanawiyata Tamansiswa Yogyakarta. Sampel penelitian dilakukan dengan menggunakan teknik Proportionate stratified random sampling dimana populasi mempunyai anggota/ unsur yang tidak homogen dan berstrata.

Berdasarkan rumus Yamane dengan populasi sebanyak 122, jumlah sampel penelitian ini 93 orang tenaga kependidikan Universitas Sarjanawiyata Tamansiswa Yogyakarta. Adapun teknik analisis data menggunakan metode analisis deskriptif dan metode analisis inferensial. Analisis deskriptif digunakan untuk menganalisa data dengan cara mendiskripsikan data yang telah terkumpul sebagaimana adanya tanpa bermaksud membuat kesimpulan yang berlaku untuk digeneralisasikan. Analisis inferensial menggunakan alat analisis Partial Least Square (PLS), yaitu SEM yang berbasis variance, dengan software Smart PLS 2.0 (Wiyono, 2011). Teknik analisis untuk mendapatkan jawaban respon responden terhadap variabel penelitian dan gambaran responden terhadap variabel-variabel penelitian melalui beberapa tahapan pengujian PLS : (1) Uji indikator/Outer Model/ Measurement Model untuk menguji hubungan antara indikator terhadap variabel konstruknya, dari uji indikator ini diperoleh output validitas dan realibilitas model; (2) Uji Hipotesis untuk menggambarkan hubungan dan pengaruh antar variabel laten berdasarkan pada substantive theory; (3) Analisis jalur untuk melakukan analisis terhadap model jalur dari suatu diagram yang menghubungkan antara variabel independen (eksogen), intervening (eksogen/endogen), dan dependen (endogen). Pola hubungan ditunjukkan dengan menggunakan anak panah dari variabel eksogen ke variabel endogen. Selain teknik analisis data digunakan juga koefisien determinasi $\left(\mathrm{R}^{2}\right)$ dan uji ketetapan parameter penduga (uji t), digunakan sebagai model dalam teknik analisis data.

\section{KAJIAN LITERATUR DAN PENGEMBANGAN HIPOTESIS}

\section{Kajian Literatur}

Manajemen sumber daya manusia (MSDM) merupakan bagian dari ilmu manajemen yang memfokuskan pembahasannya pada pengaturan peranan manusia yang ada dalam suatu organisasi. Pengaturan tersebut menurut Hasibuan (2003:10) meliputi masalah perencanaan, pengorganisasian, pengarahan, pengendalian, pengadaan, pengembangan, kompensasi, pengintegrasian, pemeliha-raan, kedisiplinan dan pemberhentian karyawan. Sedangkan pengertian MSDM menurut Mathis, Jackson (2006, p3) Manajemen Sumber Daya Manusia adalah sebuah rancangan sistem-sistem formal dalam sebuah organisasi untuk memastikan penggunaan bakat manusia secara efektif dan efisien guna mencapai tujuan-tujuan organisasional. Dari beberapa pengertian di atas maka dapat disimpulkan MSDM adalah bagaimana cara untuk dapat mengolah SDM agar dapat mencapai tujuantujuan dari suatu organisasi. Salah satu bentuk pengolah SDM ialah dengan adanya rotasi. Pelaksanaan rotasi merupakan bagian dari salah satu fungsi manajemen sumber daya manusia yaitu fungsi pengembangan. Rotasi pada umumnya meliputi kegiatan mencari, menempatkan dan mendayagunakan sumber daya manusia yang ada pada suatu perusahaan secara efektif dan efisien.

Cheraskin dan Stevens (2001, dalam BR Supratman 2012) menyatakan bahwa organisasi menggunakan rotasi pekerjaan 
sebagai sarana untuk mewujudkan high performance atau kinerja yang tinggi. Mereka juga menyatakan bahwa rotasi pekerjaan adalah pergeseran pekerjaan antar karyawan dalam organisasi. Pergeseran ini tidak dilakukan secara permanen. Kekuatan rotasi pekerjaan adalah mampu mengurangi kebosanan dan meningkatkan motivasi lewat penganekargaman kegiatan karyawan, tentu saja hal itu dapat juga mempunyai manfaat tidak langsung bagi perusahaan atau organisasi, karena karyawan dengan rentang ketrampilan yang lebih lebar memberi manajemen banyak kelenturan dalam menjadwalkan kerja, menyesuaikan diri dengan perubahan dan mengisi kekosongan personalia.

Rotasi karyawan merupakan suatu pergerakan dari satu pekerjaan ke pekerjaan lain yang biasanya tanpa mengakibatkan perubahan dalam hal gaji atau pangkat (Desler 2009). Lebih lanjut Taylor dalam Arifamrizal (2008) menjelaskan bahwa tujuan dari rotasi pekerjaan (job rotation) adalah memberikan karyawan variasi lebih dalam pekerjaannya. Rotasi pekerjaan memindahkan karyawan dari satu bidang pekerjaan khusus ke bidang lainnya. Karyawan dilatih dan diberikan kesempatan untuk melakukan dua pekerjaan atau lebih dalam sistem rotasi, dengan rotasi pekerjaan ini, manajer yakin dapat menstimulasi kemauan dan motivasi karyawan bila menyediakan karyawan perspektif yang luas dalam organisasi

Menurut Ortega, Jaime dalam tesis A. Tolkah Mansur (2009) yang berjudul "Analisa Pengaruh Budaya Organisasi dan Rotasi Pekerjaan Terhadap Motivasi Kerja Untuk Meningkatkan Kinerja Pegawai Ditjen Pajak", menjelaskan bahwa dalam rotasi kerja terdapat beberapa faktor yang dapat digunakan dalam mengukur variable tersebut, yaitu: (1) kemampuan karyawan; (2) Pengetahuan karyawan; (3) dan kejenuhan karyawan.

Kepuasan kerja dapat dijadikan suatu ukuran proses pembangunan iklim yang berkelanjutan dalam suatu organisasi. Dalam hal ini, kepuasan kerja yang tinggi diinginkan oleh para manajer karena dapat dikaitkan dengan hasil positif yang mereka harapkan, dan kepuasan kerja yang tinggi juga merupakan tanda

organisasi yang dikelola dengan baik dan pada dasarnya mencerminkan fungsi manajerial yang efektif. Kepuasan kerja berarti perasaan mendukung atau tidak mendukung yang dialami karyawan dalam bekerja. Selain itu Wether \& Davis (1996) mendefinisikan kepuasan kerja sebagai perasaan karyawan yang berhubungan dengan pekerjaannya, yaitu perasaan senang atau tidak senang dalam memandang dan menjalankan pekerja-annya. Sejalan dengan hal tersebut Handoko (2001) mengatakan kepuasan kerja merupakan keadaan emosional yang menyenangkan dimana para karyawan memandang pekerjaan mereka.

Fuad Mas'ud (2004), menyatakan bahwa ada 5 faktor yang dapat mempengaruhi kepuasan karyawan dimana faktor-faktor ini juga dapat digunakan untuk mengukur kepuasan kerja (job satisfaction), yaitu : (1) kepuasan dengan gaji; (2) kepuasan dengan promosi; (3) kepuasan dengan rekan sekerja; (4) kepuasan dengan penyelia; (5) dan kepuasan dengan pekerjaan itu sendiri.

Kinerja karyawan merupakan tingkat keberhasilan karyawan dalam menjalan-kan tugas dan tanggung jawabnya. Adapun pengertian kinerja karyawan menurut Mangkunegara (2006:9) adalah hasil kerja secara kualitas dan kuantitas yang dicapai oleh seorang karyawan dalam melaksanakan tugasnya sesuai dengan tanggung jawab yang diberikan kepadanya. Guna mengetahui karyawan melaksanakan tugas sesuai dengan tuntutan pekerjaan dan melihat apakah kinerja meningkat, maka perusahaan harus melakukan penilaian terhadap kinerja karyawan. Penilaian kinerja sangat penting bagi perusahaan, karena melalui proses ini perusahaan dapat mengetahui karyawan yang patut menerima hukuman atas kinerjanya yang buruk, atau mendapat reward atas kinerja karyawan yang meningkat dan sesuai dengan keinginan perusahaan.

Variabel kinerja karyawan dalam penelitian ini diukur oleh tujuh indikator yang dikembangkan oleh Abubakar MT Suliman 
(2002) dan McNeese-Smith (1996), yaitu : (1) kualitas hasil kerja, (2) keuletan kerja, (3) disiplin, (4) kerjasama antar rekan sekerja, (5) kepedulian akan keselamatan kerja, (6) tingkat tanggungjawab atas hasil pekerjaan, dan (7) kreativitas yang dimiliki. Namun dalam penelitian ini penulis mencoba menggabungkan tujuh variabel yang ada menjadi 3 yaitu ; (1) kualitas hasil kerja (keuletan kerja, kreativitas yang dimiliki dan kepedulian akan keselamatan kerja), (2) disiplin kerja (tingkat tanggungjawab atas hasil pekerjaan), dan (3) kerjasama antar rekan kerja .

\section{Pengembangan Hipotesis}

\section{Kerangka Pemikiran Teoritis}

Kinerja karyawan perusahaan diharapkan selalu meningkat untuk mencapai tujuan organisasi. Maka untuk meningkatkan kinerja tersebut perlu adanya kerja sama yang ada diorganisasi baik kerja sama antar atasan dan bawahan maupun kerjasama antar bawahan. Dalam era kompetitif sekarang ini dituntut adanya kinerja bawahan/ karyawan yang bagus yaitu berupa perilaku atau tindakan yang relevan dengan tujuan organisasi. Kinerja karyawan dapat dilihat dari tingkat pencapaian hasil secara kuantitas dan kualitas, efisien dan kriteria efektifitas kerja seseorang karyawan yang terkait dengan tujuan organisasi meliputi kerjasama, kreatif, dan inovatif.

Selain itu untuk meningkatkan kinerja karyawan diperlukan adanya kepuasan kerja yang merupakan prediktor komitmen organisasi. Karena kepuasan dan perasaan sebagai bagian dari tuntutan hidup, maka perasaan puas terhadap tugas atau pekerjaan, puas terhadap atasan dan puas terhadap rekan kerja, kepuasan terhadap hasil yang seimbang dan kepuasan terhadap aturan yang jelas akan mempengaruhi perasaan karyawan dan selanjutnya berdampak pada pelaksanaan aktivitas.

Uraian pemikiran yang telah disampaikan di atas memberikan landasan arah pada penyusunan kerangka pemikiran teoritis sebagai berikut :

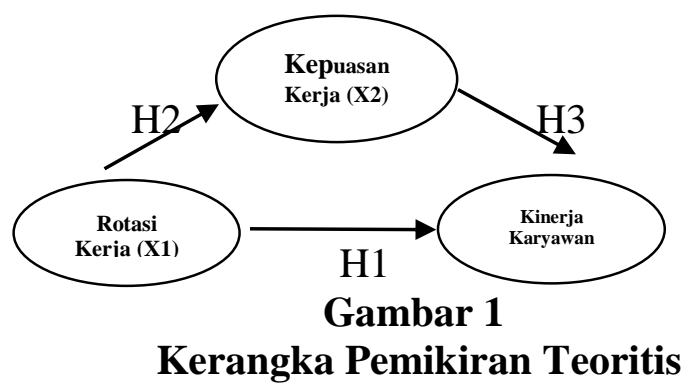

3. Definisi Operasional

3.1 Rotasi Pekerjaan

Rotasi pekerjaan yang diteliti dalam penelitian ini didefinisikan sebagai perubahan periodik karyawan dari satu tugas ke tugas lainnya. Untuk mengukur variabel rotasi pekerjaan digunakan tiga indikator yang dikembangkan oleh Ortega (2001) dan Mangiapane (1968), yaitu : (1) tambahan kemampuan, (2) tambahan pengetahuan, dan (3) tingkat kejenuhan kerja.

Campion, Cheraskin dan Stevens (1994) menyatakan bahwa organisasi menggunakan rotasi pekerjaan sebagai sarana untuk mewujudkan high performance atau kinerja yang tinggi. Campion, Cheraskin dan Stevens (1994) juga menyatakan bahwa rotasi pekerjaan adalah pergeseran pekerjaan antar pegawai dalam organisasi. Pergeseran ini tidak dilakukan secara permanen. Rotasi merupakan salah satu cara untuk menempatkan atau staffing pegawai. Sundin (2001) menambahkan bahwa alasan lain dilakukannya rotasi pekerjaan adalah bahwa tugas atau pekerjaan bersifat monoton yang dilaksanakan terus menerus dapat mengakibatkan kebosanan dan penurunan hasil kerja dari pegawai. Adanya rotasi pekerjaan diharapkan dapat menstimulasi pegawai untuk mencapai kinerja yang lebih baik karena terdapat proses penambahan pengetahuan dan kemampuan pegawai, mengurangi kejenuhan kerja dari pegawai, membantu proses penempatan pegawai secara tepat, serta memberi tantangan lebih besar bagi 
pegawai untuk mencapai prestasi atau kinerja yang lebih baik.

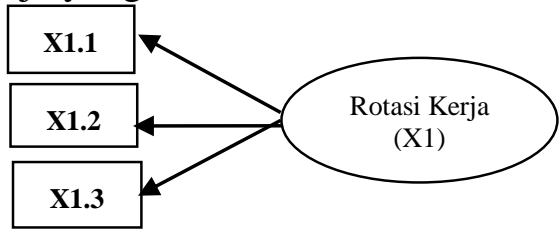

Gambar 2

Indikator Variabel Rotasi Pekerjaan Sumber : Ortega (2001) \&Mangiapane (1968)

Keterangan :
$\mathrm{X} 1.1$ :
Tambahan kemampuan
$\mathrm{X} 1.2$ :
Tambahan pengetahuan
$\mathrm{X} 1.3$ :
Tingkat kejenuhan kerja

\subsection{Kepuasan Kerja}

Kepuasan kerja sebagai tingkat kesenangan yang dirasakan seseorang atas peranan dan pekerjaan dalam suatu organisasi, Robbin (1996). Sedangkan indikator kepuasan kerja adalah : (1) kepuasan kerja sebagai respon emosional terhadap situasi kerja (kondisi kerja itu sendiri); (2) hasil kerja yang diperoleh atau yang diharapkan (pendapatan, promosi); (3) kepuasan kerja mempresentasikan beberapa sikap yang merupakan sumber kepuasan kerja (hubungan kerja dengan atasan dan rekan kerja).

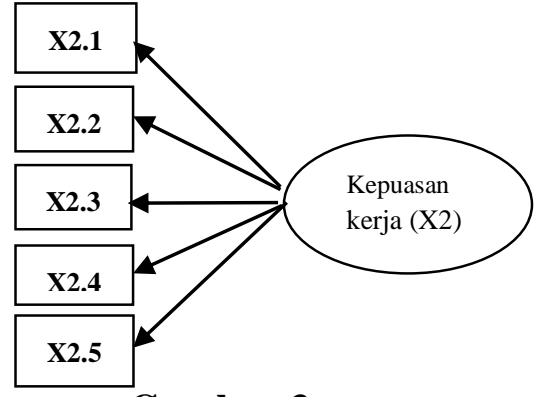

Gambar 3

Indikator Variabel Kepuasan Kerja Sumber : Robbin (1996) dalam Mas'ud (2004)

Keterangan :

X2.1 : Kepuasan terhadap atasan

$\mathrm{X} 2.2$ : Kepuasan terhadap rekan kerja

X2.3 : Kepuasan terhadap pekerjaan

X2.4 : Kepuasan terhadap peluang promosi

$\mathrm{X} 2.5$ : Kepuasan terhadap pendapatan

\subsection{Kinerja Karyawan}

Kinerja karyawan adalah hasil yang telah dicapai dari yang telah dilakukan, dikerjakan seseorang dalam melaksanakan kerja atau tugas. Variabel kinerja karyawan dalam penelitian ini diukur oleh tujuh indikator yang dikembangkan oleh Abubakar MT Suliman (2002) dan McNeese-Smith (1996), yaitu : (1) kualitas hasil kerja, (2) keuletan kerja, (3) disiplin, (4) kerjasama antar rekan sekerja, (5) kepedulian akan keselamatan kerja, (6) tingkat tanggungjawab atas hasil pekerjaan, dan (7) kreativitas yang dimiliki. Namun dalam penelitian ini penulis mencoba menggabungkan tujuh variabel yang ada menjadi 3 yaitu; (1) kualitas hasil kerja (keuletan kerja, kreativitas yang dimiliki dan kepedulian akan keselamatan kerja), (2) disiplin kerja (tingkat tanggungjawab atas hasil pekerjaan), dan (3) kerjasama antar rekan kerja .

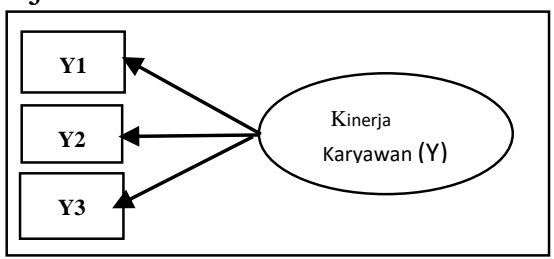

Gambar 4

Indikator Variabel Kinerja Karyawan

Sumber : Abubakar MT Sulaiman (2002) dan MC Neese-Smith (1996)

Keterangan :

Y1: Kualitas hasil kerja (keuletan kerja, kreativitas yang dimiliki dan kepedulian akan keselamatan kerja.

Y2: Disiplin kerja (tingkat tanggungjawab atas hasil pekerjaan)

Y3 : Kerjasama antar rekan kerja Berdasarkan definisi di atas serta kerangka, maka variabel dan indikator yang di analisis dalam penelitian ini, disajikan pada tabel 1 berikut : 
Tabel 1

Indikator Variabel Penelitian

\begin{tabular}{|c|c|c|c|}
\hline No & Variabel & Indikator & $\begin{array}{c}\text { Kepustak } \\
\text { aan }\end{array}$ \\
\hline 1. & $\begin{array}{l}\text { Rotasi } \\
\text { Kerja }\end{array}$ & $\begin{array}{l}\text { - Perubahan } \\
\text { periodik } \\
\text { karyawan } \\
\text { dari satu } \\
\text { tugas ke } \\
\text { tugas } \\
\text { lainnya } \\
\text { - Persepsi } \\
\text { menambah } \\
\text { pengetahuan } \\
\text { dan } \\
\text { pengalaman } \\
\text { - Persepsi } \\
\text { mengurangi } \\
\text { tingkat } \\
\text { kejenuhan } \\
\text { kerja } \\
\text { - Persepsi } \\
\text { penempatan } \\
\text { karyawan } \\
\text { pada posisi } \\
\text { yang tepat } \\
\text { dan sesuai } \\
\text { kemampuan }\end{array}$ & $\begin{array}{l}\text { Ortega } \\
(2001)\end{array}$ \\
\hline 2. & $\begin{array}{l}\text { Kepuasa } \\
\text { n Kerja }\end{array}$ & $\begin{array}{l}\text { - Pekerjaan } \\
\text { yang sangat } \\
\text { menarik } \\
\text { - Lebih suka } \\
\text { melaksanaka } \\
\text { n pekerjaan } \\
\text { lain } \\
\text { - Tunjangan } \\
\text { yang } \\
\text { diperoleh } \\
\text { cukup } \\
\text { memadai } \\
\text { - Memiliki } \\
\text { kesempatan } \\
\text { yang sama } \\
\text { untuk } \\
\text { peningkatan } \\
\text { dan }\end{array}$ & $\begin{array}{l}\text { Mas'ud } \\
\text { (2004) }\end{array}$ \\
\hline
\end{tabular}

\begin{tabular}{|c|c|c|c|}
\hline & & $\begin{array}{l}\text { pengembang } \\
\text { an karier } \\
\text { - Supervisor } \\
\text { memberi } \\
\text { dukungan } \\
\text { - Supervisor } \\
\text { mempunyai } \\
\text { motivasi } \\
\text { kerja tinggi } \\
\text { - Rekan kerja } \\
\text { kooperatif } \\
\text { dan } \\
\text { memiliki } \\
\text { hubungan } \\
\text { yang baik }\end{array}$ & \\
\hline 3. & $\begin{array}{l}\text { Kinerja } \\
\text { Karyaw } \\
\text { an }\end{array}$ & $\begin{array}{l}\text { - Kualitas } \\
\text { hasil } \\
\text { karyawan } \\
\text { (Keuletan } \\
\text { kerja, } \\
\text { kreatifitas, } \\
\text { kepedulian } \\
\text { akan } \\
\text { keselamatan } \\
\text { kerja) } \\
\text { - Disiplin } \\
\text { kerja } \\
\text { - Memiliki } \\
\text { semangat } \\
\text { tim dalam } \\
\text { menyelesaik } \\
\text { an pekerjaan }\end{array}$ & $\begin{array}{l}\text { Abubakar } \\
\text { MT } \\
\text { Sulaiman } \\
\text { (2002) } \\
\text { dan MC } \\
\text { Neese- } \\
\text { Smith } \\
\text { (1996) }\end{array}$ \\
\hline
\end{tabular}

\section{Hipotesis}

Berdasarkan latar belakang dan tinjauan pustaka serta kerangka pemikiran teoritis maka penulis mengajukan suatu hipotesis. Pada sebuah penelitian terdapat hipotesis yang akan diuji, terlebih lagi dalam sebuah penelitian kuantitatif. Menurut Arikunto (1998:64) secara bahasa hipotesis berasal dari kata hypo yang berarti di bawah, thesa yang artinya kebenaran, jadi hipotesis yang penulisannya disesuaikan dengan ejaan Bahasa Indonesia menjadi hipotesa dan berkembang menjadi hipotesis.

Menurut Sugiyono (2011:99) hipotesis mrupakan jawaban sementara terhadap 
rumusan masalah penelitian, dimana rumusan masalah penelitian telah dinyakatan dalam bentuk kalimat pertanyaan. Hipotesis yang diambil dari penelitian ini adalah :

$\begin{array}{rlr}\text { H1 : } & \text { Rotasi kerja mempunyai } \\ & \text { pengaruh yang positif dan } \\ & \text { signifikan (negatif) terhadap } \\ & \text { kepuasan kerja tenaga } \\ & \text { kependidikan Universitas } \\ \text { H2 : } & \text { Rarjanawiyata Tamansiswa. } \\ & \text { pengaruh yang positif dan } \\ & \text { signifikan (negatif) terhadap } \\ & \text { kinerja tenaga kependidikan } \\ & \text { Universitas Sarjanawiyata } \\ & \text { Tamansiswa. } \\ \text { H3 : } & \text { Kepuasan kerja mempunyai } \\ & \text { pengaruh yang positif dan } \\ & \text { signifikan (negatif) terhadap } \\ & \text { kinerja tenaga kependidikan } \\ & \text { Universitas Sarjanawiyata } \\ & \text { Tamansiswa. }\end{array}$

\section{METODE PENELITIAN}

\section{Jenis dan Sumber Data}

Data yang dipergunakan dalam penelitian ini adalah data subyek (data yang bersifat personal/perorangan) karena berupa sikap, opini, pengalaman atau karakteristik seorang atau sekelompok orang, dimana yang menjadi subyek penelitian adalah tenaga kependidikan di Universitas Sarjanawiyata Tamansiswa. Data obyek yang digunakan dalam penelitian ini adalah rotasi kerja, kepuasan kerja dan kinerja tenaga kependidikan pada Universitas Sarjanawiyata Tamansiswa.

Sedangkan jenis data yang digunakan adalah data primer dimana data diperoleh langsung dari sumber data tanpa melalui perantara yaitu dengan mengambil data dari responden dan juga menggunakan data sekunder (data pendukung) yaitu data yang didapat tidak secara langsung atau data yang telah diolah oleh pihak lain (Nur Indriantoro, 1999). Sumber data dalam penelitian ini adalah sumber data primer, data yang di ambil langsung dari sumbernya (objek penelitian). Dalam penelitian ini terdapat 11 indikator yang menjadi data primer yang terdiri atas : rotasi pekerjaan (3 data), kepuasan kerja (5 data) dan kinerja karyawan (3 data). Data-data ini diperoleh langsung dari penyebaran daftar pertanyaan kepada tenaga kependidikan Universitas Sarjanawiyata Tamansiswa.

\section{Populasi dan Sampel}

\section{a. Populasi}

Populasi adalah sekelompok orang, kejadian atau segala sesuatu yang mempunyai karakteristik tertentu, anggota populasi disebut elemen polupasi (Nur Indriantoro, 1987). Populasi penelitian ini adalah seluruh tenaga kependidikan Universitas Sarjanawiyata Tamansiswa Yogyakarta yang berjumlah 122 orang.

\section{b. Sampel}

Untuk melakukan penelitian seorang peneliti dapat meneliti sebagian (sampel) atau seluruhnya (sensus) Nur Indriantoro (1987). Penelitian tersebut menggunakan sampel atau sebagian elemen populasi yang akan mewakili pendapat dari seluruh populasi.

Sedangkan metode pemilihan sampel yang digunakan adalah Proportionate stratified random sampling dimana populasi mempunyai anggota/unsur yang tidak homogen dan berstrata, adapun kriteria subyek yang dipakai ialah :

a) Tenaga kependidikan di Universitas Sarjanawiyata Tamansiswa.

b) Pendidikan terakhir tenaga kependidikan.

c) Memiliki masa kerja 1 tahun ke atas. Hal ini dikarenakan pada tahun pertama kerja adalah dianggap sebagai masa percobaan.

Pengambilan sampel harus sesuai dengan kriteria tersebut, karena akan berpengaruh pada variabel yang akan diteliti. Penentuan jumlah sampel dapat dihitung dari populasi tertentu yang sudah diketahui jumlahnya. Menurut rumus 
Yamane (Ferdinand, 2006) adalah sebagai berikut:

$$
\mathbf{n}=\frac{\mathbf{N}}{\mathbf{1}+\mathbf{N d}^{2}}
$$

dimana:

$\mathrm{n}=$ jumlah sampel

$\mathrm{N}=$ ukuran populasi

$\mathrm{d}=$ prosentasi kelonggaran ketidaktelitian

$$
\mathrm{n}=\frac{122}{1+122(5 \%)^{2}}=93,4
$$

Jumlah populasi tenaga kependidikan Universitas Sarjanawiyata Tamansiswa yaitu 122 pegawai, setelah di hitung dengan rumus Yamane (1973) dalam Ferdinand (2006) maka di dapatkan sampel sebanyak 93 pegawai, sedangkan pengambilan sampel di lakukan secara Proportionate stratified random sampling.

\section{Variabel Penelitian}

Variabel adalah segala sesuatu yang akan menjadi obyek pengamatan dalam suatu penelitian. Selanjutnya dalam penelitian ini terdapat dua variabel independen (bebas) dan satu variabel dependen (terikat), sebagai berikut :

a. Rotasi kerja (X1), sebagai variabel bebas

b. Kepuasan kerja (X2), sebagai variabel bebas

c. Kinerja karyawan $\quad(\mathrm{Y}), \quad$ sebagai variabel terikat

Variabel rotasi kerja memiliki indikator kemampuan, pengetahuan dan kejenuhan kerja (Ortega, 2001), alat ukur ini sudah teruji pada penelitian yang dilakukan oleh A. Tolkah Mansur (2009) yang menyatakan bahwa rotasi pekerjaan berpengaruh positif terhadap kinerja pegawai, karena

diharapkan adanya rotasi pekerjaan dapat menstimulasi pegawai untuk mencapai kinerja lebih baik karena terdapat proses penambahan pengetahuan dan kemampuan pegawai, mengurangi kejenuhan kerja pegawai, membantu proses penempatan pegawai untuk mencapai prestasi atau kinerja yang lebih baik.
Variabel kepuasan kerja memiliki alat ukur kepuasan terhadap atasan, kepuasan terhadap rekan kerja, kepuasan terhadap pekerjaan, kepuasan terhadap peluang promosi dan kepuasan terhadap pendapatan/gaji (Mas'ud, 2004), alat ukur ini telah dibuktikan dalam penelitan Deewar Mahesa (2010.), terhadap kinerja pegawai, hal ini menunjukkan bahwa semakin tinggi kepuasan kerja yang dirasakan karyawan, maka kinerja karyawan akan meningkat atau sebaliknya semakin rendah kepuasan kerja maka semakin rendah kinerja karyawan.

Variabel kinerja memiliki alat ukur kualitas hasil kerja (hasil pekerjaan yang dilakukan mendekati sempurna atau memenuhi tujuan yang diharapkan dari pekerjaan), disiplin kerja dan kerjasama, hal ini sudah dibuktikan dalam penelitian Rani Mariam (2009).

\section{Metode Pengumpulan Data}

Untuk mengumpulkan data penelitian, kuesioner dipilih sebagai metode pengumpulan data dalam penelitian ini. Pertanyaan dalam kuesioner diuji dengan menggunakan skala likert $1-5$ untuk mendapatkan data yang bersifat internal dan diberi skor sebagai berikut :

Tabel 2

\begin{tabular}{|c|c|c|}
\hline Perayatasa & Disiugkat & Skor \\
\hline Sragat 7idak Setigna & STS & 1 \\
\hline Tidd: Sexojn & IS & 2 \\
\hline Netral & $\mathrm{H}$ & 3 \\
\hline Setijn & $\$$ & 4 \\
\hline Srgat Setigi & $\mathbb{S S}$ & 5 \\
\hline
\end{tabular}

\section{Pengukuran Kuesioner}

Untuk ketepatan pernyataan agar data yang terkumpul mengarah tepat pada model maka dilakukan uji validitas dan uji reliabilitas.

\section{Uji Instrumen}

Instrumen yang digunakan dalam bentuk kuesioner harus mengukur senyatanya (actually) dan seakuratnya (accurately) apa yang seharusnya diukur dari konsep. Pengukuran konsep yang senyatanya 
berhubungan dengan validitas, dan pengukuran seakuratnya berhubungan dengan reliabilitas.

\section{a. Uji Validitas}

Uji validitas dilakukan dengan cara mengkorelasikan antara skor item dengan skor total item (Wiyono, 2011:139). Pengujian dilakukan 2 sisi dengan signifikansi 0,05. Item pertanyaan/ pernyataan dinyatakan valid jika berkorelasi signifikan terhadap skor totalnya. Untuk melakukan uji validitas, menggunakan teknik analisis korelasi bivariate pearson. Dinyatakan signifikan jika, nilai sig. dua sisi dibawah 0,05 atau nilai pearson correlation ( $r$ hitung) diatas $r$ tabel. Pengujian dilakukan dengan menggunakan software SPSS ver. 17.00

\section{b. Uji Reliabilitas}

Uji reliabilitas menggunakan metode Alpha (Cronbach's) dengan taraf signifikansi 0,05 (Wiyono, 2011:143). Instrument dikatakan reliabel apabila nilai alpha > nilai $\mathrm{r}$ product moment. Menurut Sekaran (1992), reliabilitas kurang baik jika diperoleh nilai alpha kurang dari 0,6, sedangkan 0,7 dapat diterima dan diatas 0,8 adalah baik. Pengujian dilakukan dengan menggunakan software SPSS ver. 17.00.

\section{Metode Analisis data}

Dalam penelitian ini analisis yang dilakukan dengan menggunakan metode analisis deskriptif dan metode analisis inferensial.

\section{a. Analisis Deskriptif}

Analisis deskriptif adalah statistik yang digunakan untuk menganalisa data dengan cara mendiskripsikan data yang telah terkumpul sebagaimana adanya tanpa bermaksud membuat kesimpulan yang berlaku untuk digeneralisasikan. Telah disampaikan diatas pada Sub-Bab Metode Pengumpulan Data, katagori data dibagi menjadi 5 (lima) dari skor 1 sampai dengan 5. Untuk mengelompokkan data pada masing-masing katagori tersebut, perlu dibuat range (interval) dengan rumus berikut ini :

$$
I n t=\frac{\sum S_{\max }-\sum S_{\min }}{\sum_{i=1}^{n} K_{i}}
$$

Dimana:

Int $\quad=$ Interval

$\sum S_{\text {Max }}=$ Skor Total Maksimum

$\sum S_{\text {Min }}=$ Skor Toral Minimum

$\sum_{i=1}^{n} K_{i} \quad=$ Jumlah Kategori

\section{b. Analisis Inferensial}

Guna melakukan analisis inferensial dari penelitian ini, alat analisis yang digunakan adalah Partial Least Square (PLS), yaitu SEM yang berbasis variance, dengan software Smart PLS 2.0 (Wiyono, 2011). Tahapan pengujian PLS dilakukan sebagai berikut:

\section{1) Uji Indikator}

Uji indikator atau disebut juga Outer Model atau Measurement Model adalah menguji hubungan antara indikator terhadap variabel konstruknya, dari uji indikator ini diperoleh output validitas dan realibilitas model yang diukur dengan kriteria: Convergent Validity, Discriminant Validity, dan Composite Reliability.

Convergent Validity

Diukur dari korelasi antara skor indikator dengan konstruknya. Indikator individu dianggap valid jika memiliki nilai korelasi di atas 0,50. Apabila ada indikator yang tidak memenuhi syarat ini maka harus dibuang.

Discriminant Validity

Diukur dari cross loading antara indikator dengan konstruknya. Indikator dinyatakan valid jika hubungan indikator dengan konstruknya lebih tinggi dibandingkan dengan hubungannya dengan konstruk yang lain.

\section{Composite Reliability}


Konstruk dinyatakan reliabel apabila composite reliability memiliki nilai diatas 0,70 .

\section{2) Uji Hipotesis}

Inner Model atau structural model sebenarnya merupakan uji hipotesis, menggambarkan hubungan dan pengaruh antar variabel laten berdasarkan pada substantive theory. Model persamaannya dapat dituliskan seperti dibawah ini :

Dimana:

$$
\eta=\beta_{0}+\beta \eta+r \xi+\zeta
$$

$\eta=$ vector endogen (dependen) variabel laten

$\xi=$ vector exogen (independen) variabel laten

$\zeta=$ vector residual

Oleh karena PLS didesain untuk model recursive, maka hubungan antar variabel laten dapat dispesifikasikan sebagai berikut:

$$
\eta_{\mathrm{j}}=\sum_{\mathrm{i}} \beta_{\mathrm{ji}} \eta_{\mathrm{i}}+\sum_{\mathrm{i}} \gamma_{\mathrm{j} b} \xi_{\mathrm{b}}+\zeta_{\mathrm{j}}
$$

Dimana:

$\beta_{\mathrm{ji}}$ dan $\gamma_{\mathrm{jb}}$ adalah koefisien jalur yang menghubungan predictor endogen dan variabel laten exogen $\xi_{\mathrm{b}}$ dan $\eta_{\mathrm{i}}$ sepanjang range indeks $I$ dan $b$. Sedangkan $\zeta_{\mathrm{j}}$ adalah inner residual variabel.

Inner model merupakan pengujian terhadap model structural dilakukan dengan melihat nilai $R$ square sebagai uji goodness of fit model. Selain itu juga dilakukan uji signifikansi pengaruh antar konstruk dengan melihat nilai koefisien parameter dan nilai signifikansi t-statistiknya.

\section{Kriteria Penilaian PLS}

Sebagai tambahan penjelasan dari penggunaan PLS ini, disampaikan kriteria penilaian model PLS sebagaimana diajukan oleh Chin (1998) dalam Ghozali (2008) seperti tabel berikut ini.
Tabel 3

\begin{tabular}{|c|c|c|}
\hline $\begin{array}{l}\text { UJI } \\
\text { MODEL }\end{array}$ & OUTPUT & KRITERIA \\
\hline \multirow{3}{*}{$\begin{array}{l}\text { Outer } \\
\text { Model } \\
\text { (Uji } \\
\text { Indikator) }\end{array}$} & $\begin{array}{l}\text { Convergent } \\
\text { Validity. }\end{array}$ & $\begin{array}{l}\text { Nilai loading } \\
\text { factor }>0,50\end{array}$ \\
\hline & $\begin{array}{l}\text { Discrimina } \\
n t \text { Validity. }\end{array}$ & $\begin{array}{l}\text { Nilai korelasi } \\
\text { cross loading } \\
\text { dengan variabel } \\
\text { latennya harus } \\
\text { lebih besar } \\
\text { dibandingkan } \\
\text { korelasi terhadap } \\
\text { variabel laten yang } \\
\text { lain. }\end{array}$ \\
\hline & $\begin{array}{l}\text { Composite } \\
\text { Reliability. }\end{array}$ & $\begin{array}{l}\text { Nilai Composite } \\
\text { reliability yang } \\
\text { baik apabila } \\
\text { memiliki nilai } \geq \\
0,70\end{array}$ \\
\hline \multirow[t]{2}{*}{$\begin{array}{l}\text { Inner } \\
\text { Model } \\
\text { (Uji } \\
\text { Hipotesis) }\end{array}$} & $\begin{array}{l}\mathrm{R}^{2} \text { untuk } \\
\text { variabel } \\
\text { laten } \\
\text { endogen }\end{array}$ & $\begin{array}{l}\text { Hasil R² sebesar } \\
0,67 ; 0,33 ; \text { dan } \\
0,19 \\
\text { mengindikasikan } \\
\text { bahwa model } \\
\text { "Baik", } \\
\text { "Moderat", } \\
\text { dan"Lemah". }\end{array}$ \\
\hline & $\begin{array}{l}\text { Koefisien } \\
\text { Parameter } \\
\text { dan T- } \\
\text { Statistik }\end{array}$ & $\begin{array}{l}\text { Nilai estimasi } \\
\text { untuk hubungan } \\
\text { jalur dalam model } \\
\text { struktural harus } \\
\text { signifikan, yang } \\
\text { dapat diperoleh } \\
\text { dengan prosedur } \\
\text { bootstrapping. }\end{array}$ \\
\hline
\end{tabular}

Kriteria Penilaian PLS

\section{c. Analisis Jalur}

Analisis jalur pada prinsipnya adalah melakukan analisis terhadap model jalur dari suatu diagram yang menghubungkan antara variabel independen (eksogen), intervening (eksogen/endogen), dan dependen (endogen). Pola hubungan ditunjukkan dengan menggunakan anak panah dari variabel eksogen ke variabel endogen. Menurut Sarwono (2007), analisis jalur dapat dilakukan dengan menghitung pengaruh langsung (Direct 
Effect), pengaruh tidak langsung (Indirect Effect), dan pengaruh total (Total Effect), dengan formula sebagai berikut:

1) Pengaruh Langsung

$\mathrm{X}_{1} \rightarrow \mathrm{X}_{2}=$ sebesar koefisien parameter sesuai output (a) $\mathrm{X}_{1} \rightarrow \mathrm{Y} \quad=\quad$ sebesar koefisien parameter sesuai output (b) $\mathrm{X}_{2} \rightarrow \mathrm{Y}=$ sebesar koefisien parameter sesuai output (c)

2) Pengaruh Tidak Langsung $\mathrm{X}_{1} \rightarrow \mathrm{X}_{2} \rightarrow \mathrm{Y}=$ sebesar a $\mathrm{x} \mathrm{c}(\mathrm{d})$

3) Pengaruh Total $\mathrm{X}_{1} \rightarrow \mathrm{X}_{2} \rightarrow \mathrm{Y}=$ sebesar $\mathrm{a}+\mathrm{d}$

\section{HASIL dan PEMBAHASAN}

\section{Pengaruh Rotasi Kerja terhadap Kepuasan Kerja}

Berdasarkan dari hasil analisis data diketahui bahwa rotasi kerja berpengaruh positif dan signifikan terhadap kepuasan kerja kerja hal ini karena diperoleh nilai $t$ hitung statistik $>\mathrm{t}$ table, yaitu sebesar 4,625796 (46\%) sedangkan $t$ tabel sebesar 1,6614 .

Implementasi rotasi ke unit kerja yang sesuai dengan kemampuan dan keahlian pegawai akan menimbulkan kepuasan kerja pegawai. Tujuan utama rotasi dilakukan adalah untuk menyesuaikan kemampuan pegawai dengan jenis pekerjaan yang ada. Kebijakan rotasi kerja dapat bermafaat dalam menyesuaikan pegawai pada posisi pekerjaan baru yang sesuai dengan background pendidikan pegawai. Hasil penelitian ini mendukung teori Robbins (2003:235) dan hasil penelitian terdahulu oleh Wen-Hsien Ho et al. (2009) dan Adomi (2005) bahwa rotasi kerja dapat membantu karyawan mengurangi kebosanan dan menghilangkan ketidakpuasan kerja.

\section{Pengaruh Kepuasan Kerja terhadap Kinerja Tenaga Kependidikan}

Berdasarkan dari hasil analisis data diketahui bahwa kepuasan kerja berpengaruh positif dan signifikan terhadap kinerja ini karena diperoleh nilai t-hitung statistik $>\mathrm{t}$ table, yaitu sebesar 4,502511 sedangkan $\mathrm{t}$ tabel sebesar 1,6614.Ini sesuai dengan ungkapan bahwa kepuasan kerja adalah keadaan emosional yang menyenangkan atau tidak menyenangkan dengan mana para karyawan memandang pekerjaan mereka. Kepuasan kerja mencerminkan perasaan seseorang terhadap pekerjaannya. Ini nampak dalam sikap positif karyawan terhadap pekerjaan dan segala sesuatu yang dihadapi di lingkungan kerjanya (Handoko, 2001). Menurut Keith Davis (1985) dalam Mangkunegara (2000) kepuasan kerja adalah perasaan menyokong atau tidak menyokong yang dialami pegawai dalam bekerja. Kepuasan kerja menjadi hal penting karena dapat mempengaruhi kinerja karyawan menurut Edward Lawler (Steer \& Porter, 1991) sebab seseorang memiliki kepuasan yang tinggi akan memandang pekerjaanya sebagai hal yang menyenangkan, berbeda dengan karyawan yang memiliki kepuasan kerja rendah, ia akan melihat pekerjaannya sebagai hal yang menjemukan dan membosankan sehingga karyawan tersebut bekerja dalam keadaan terpaksa. Seseorang yang bekerja dalam keadaan terpaksa akan memiliki hasil kerja yang buruk dibandingkan dengan karyawan yang bekerja dengan semangat tinggi.

Sebagian peneliti lain berpendapat bahwa yang terjadi adalah sebaliknya, yaitu kinerja mengakibatkan kepuasan. Hal ini terjadi berdasarkan pemikiran bahwa dengan kinerja yang baik, karyawan akan mendapatkan penghargaan seperti promosi, insentif atau perhatian lebih dari atasan. Penghargaan tersebut mendorong terjadinya kepuasan kerja (Cruden, 1988). Setidaknya penelitian yang menggunakan hipotesa kepuasan kerja menimbulkan kinerja dilakukan oleh Ostroff (1992), Blau (1967) dengan anggapan bahwa karyawan akan memberikan yang terbaik bagi organisasi apabila mereka juga mendapatkan yang terbaik dari organisasi dimana mereka bekerja (Morrison, 1997).

\section{Pengaruh Rotasi Kerja terhadap Kinerja Tenaga Kependidikan}


Berdasarkan dari hasil analisis data diketahui bahwa rotasi kerja berpengaruh positif namun tidak signifikan terhadap kinerja ini karena diperoleh nilai t-hitung statistik < t table, yaitu sebesar 0,69504 sedangkan $\mathrm{t}$ tabel sebesar 1,6614, namun pengaruh rotasi kerja terhadap kinerja karyawan mampu memberikan kontribusi terhadap kinerja tenaga kependidikan Universitas Sarjanawiyata Tamansiswa. Rotasi merupakan salah satu cara untuk menempatkan atau staffing pegawai. Sundin (2001) menambahkan bahwa alasan lain dilakukannya rotasi pekerjaan adalah bahwa tugas atau pekerjaan bersifat monoton yang dilaksanakan terus menerus dapat mengakibatkan kebosanan dan penurunan hasil kerja dari pegawai. Adanya rotasi pekerjaan diharapkan dapat menstimulasi pegawai untuk mencapai kinerja yang lebih baik karena terdapat proses penambahan pengetahuan dan kemampuan pegawai, mengurangi kejenuhan kerja dari pegawai, membantu proses penempatan pegawai secara tepat, serta memberi tantangan lebih besar bagi pegawai untuk mencapai prestasi atau kinerja yang lebih baik.

\section{KESIMPULAN}

Berdasarkan analisis deskriptif, analisis inferensial, analisis jalur serta pembahasan pada Bab IV, selanjutnya dapat ditarik kesimpulan sebagai berikut :

a. Dari penelitian yang telah dilakukan dapat disimpulkan bahwa "rotasi kerja berpengaruh positif dan signifikan terhadap kepuasan kerja" dapat di buktikan secara empiris dan bedasarkan analisis deskriptif dari responden (tenaga kependidikan UST) yang mempersepsikan bahwa rotasi kerja akan menambah wawasan baru dalam bekerja $(20,43 \%)$, rotasi kerja menambah ketrampilan/kemampuan dalam bekerja $(17,20 \%)$, dan rotasi kerja menghilangkan kebosanan/kejenuhan dalam bekerja $(15,05 \%)$.

b. Dari penelitian yang telah dilakukan dapat disimpulkan bahwa "kepuasan kerja berpengaruh positif dan signifikan terhadap kinerja tenaga kependidikan Universitas
Sarjana-wiyata Tamansiswa" dapat di buktikan secara empiris dan juga berdasarkan analisis deskriptif dimana responden menyebutkan bahwa atasan memberi kesempatan untuk menggunakan kemampuan dalam bekerja $(67,74 \%)$, karyawan memiliki kesempatan yang sama untuk peningkatan dan pengembangan karir $(65,59 \%)$, serta memiliki hubungan yang baik dengan rekan kerja $(41,94 \%)$, merupakan bagian dari adanya kepuasan kerja yang dapat mempengaruhi kinerja tenaga kependidikan UST.

c. Dari penelitian yang telah dilakukan dapat disimpulkan bahwa "rotasi kerja berpengaruh positif namun tidak signifikan terhadap kinerja tenaga kependidikan Universitas Sarjanawiyata Tamansiswa" dapat di buktikan secara empiris dan juga senada dengan jawaban dari responden bahwa dimanapun mereka di rotasi mereka menyatakan bahwa karyawan akan melaksanakan pekerjaan dengan penuh rasa tanggungjawab sebesar $73,12 \%$, karyawan selalu menyelesaikan pekerjaannya sesuai waktu yang telah ditentukan sebesar $68,82 \%$, dan sebesar $67,74 \%$ menyatakan bahwa untuk meningkatkan prestasi kerja harus dapat memanfaatkan waktu dan mempergunakan fasilitas yang diberikan serta tidak menunda pekerjaan, namun tenaga kependidikan menyatakan bahwa dalam penempatan rotasi hendaknya disesuaikan dengan kemampuan dan keahlian yang dimiliki oleh tenaga kependidikan atau dengan kata lain pimpinan harus mempertimbangkan the right man on the right place.

\section{DAFTAR PUSTAKA}

Blau, Gray. 1999, Testing The Longitudinal Impact of Work Variables and Performance Appraisal Satisfaction on Subsequent Overall Job Satisfaction. Human Relations. 52, 8, p 1099 (1).

Ferdinand, Augusty, 2006, Metode Penelitian Manajemen, Semarang : Badan Penerbit Universitas Diponegoro.

Hasibuan, Malayu 2000, Manajemen Sumber Daya Manusia, Jakarta : CV Masagungg. 
Herpen, Marco; Praag, Mirjan and Cools, Kess, 2002, "The Effects of Performance Measurement and Compensation on Motivation and Empirical Study", Conference of The Performance Measurement Association in Boston.

Kinman, Gail and Kinman, Russell, 2001, "The Role of Motivation to Learn in Management Education", Journal of Workplace Learning, Vol. 3, No.

Masrukhin dan Waridin, 2006, "Pengaruh Motivasi Kerja, Kepuasan Kerja, Budaya Organisasi dan Kepemimpinan terhadap Kinerja Pegawai", Jurnal Ekonomi \& Bisnis, Vol. 7, No. 2.

Mangiapane, Adele R, 1988, "Empowering People To Improve a Process",

Manufacturing Systems, Vol. 6, No. 1.

Mangkuprawira, Tb. Sjafri, 2009, Horison Bisnis, Manajemen dan Sumberdaya Manusia, Bogor : PT. Gramedia.

Mathis, R. L., Jackson, John H., 2002. Manajemen Sumber Daya Manusia. Jakarta: Salemba Empat.

McNeese-Smith, Donna, 1996, “Increasing Employee Productivity, Job Satisfaction \& Organizational Commitment", Hospital \& Health Services Administration, Vol. 41, No. 2.

Mourdoukoutas, Panos, 1994, "Job Rotation and Public Policy: Theory with Applications to Japan and The USA " International Journal of Manpower, Vol.15.

Muhadi, 2007. "Analisis Pengaruh Kepuasan Kerja Terhadap Komitmen Organisasional dalam Mempengaruhi Kinerja Karyawan" (Studi pada Karyawan Administrasi Univeristas Diponegoro)

Ninik Muljani, 2002, "Kompensasi sebagai Motivator untuk Meningkatkan Kinerja Pegawai", Jurnal Manajemen \& Kewirausahaan, Vol. 4, No.2.

Ortega, Jaime, 2001, “Job Rotation as a Learning Mechanism", Management Science, Vol. 47 No. 10.
Porter, L.W. Steers, R.M., Mowday, R.T., 1983, Organizational Commitment Job Satisfaction, and Turnover Among Psychiatric Technicians, Journal of Applied Psycology.

Rani Mariam, 2009, Pengaruh Gaya Kepemimpian dan Budaya Organisasi terhadap Kinerja Karyawan melalui Kepuasan Kerja Karyawan sebagai Variabel intervening \{studi pada kantor Pusat PT Asuransi Jaya Indosesia (Persero) $\}$

Rivai, Veithzal, 2001, "Beberapa Upaya Untuk Meningkatkan Motivasi Kerja Profesional Staf ( Survei di Bank Pemerintah Bank Mandiri., Bank BRI, Bank BRI dan Bank BTN tahun 2000)", Jurnal Ekonomi Perusahaan, Juli.

Robbins, S.P, 2003, Organizational Behaviour Concept, Contoversiest, Applications, 6Ed, Prentice Hall, Inc. Eaglewood, Cliff, New Jersey.

Robbins, S.P, 2006, Perilaku Organisasi, Edisi 10, PT. Indeks Kelompok Gramedia

Steers, R.M and Porter, R. W.1983. Motivation and Work Behavior. New York: Mc Graw Hill.

Sundin, Elisabeth, 2001, "Grender-determined Jobs and Job-rotation-Problems and Possibilities", The Service Industries Journal, Vol. 21, No. 3.

Teuku Sut Ibrahim, 2012, Pengaruh Kepuasan Kerja terhadap Kinerja Pegawai pada Inspektorat Kabupaten Aceh Utara.

Veithzal Rivai dan Ahmad Fawzi Mohd Basri, 2005, Performance Appraisal : Sistem yang Tepat Untuk Menilai Kinerja Pegawai dan Meningkatkan Daya Saing Perusahaan, Divisi Buku Perguruan Tinggi, PT. Raja Grafindo Persada, Jakarta.

Waridin dan Masrukhin, 2006, "Pengaruh Motivasi Kerja, Kepuasan Kerja, Bidaya Organisasi, dan Kepemimpinan Terhadap Kinerja Pegawai”, Ekobis, Vol.7, No.2.

Wen-hsein Ho, Ching S Chang, Ying -Ling shih and Rong_Da Liang.2009. Effect of job 
rotation and role sress among nurses on job satisfaction and organizational commitment.

Wiyono, Gendro, 2011, Merancang Penelitian Bisnis dengan Alat Analisis, SPSS 17.0 dan Smart PLS, UPP STIM YKPN.

Yuyuk Liliana, 2012, "Rotasi Kerja, Stress, Kepuasan Kerja dan Komitmen Organisasi di Pebankan Kota Malangang”, STIE Malangkucecwara. 